ISSN 1027-5495. Functional Materials, 25, No.2 (2018), p. 364-370

doi:https://doi.org/10.15407/fm25.02.364

(C) 2018 - STC “Institute for Single Crystals"

\title{
Application of slag refining technique to metallurgical grade silicon purification process: A review
}

\author{
Rowaid Al-khazraji ${ }^{1,2}$, Yaqiong Li, Lifeng Zhang ${ }^{1,2}$ \\ 1, School of Metallurgical and Ecological Engineering, University of Science \\ and Technology Beijing, Beijing, 100083, China \\ 2, Beijing Key Laboratory of Green Recycling and Extraction of Metal, \\ University of Science \& Technology Beijing, Beijing 100083
}

Received January 15, 2018

\begin{abstract}
The photovoltaic generates electricity through direct conversion of sunlight, has fastgrowing recently due to high global energy demand. Photovoltaic main material is silicon which needs refining process to fulfill the requirements. In this paper, the principle of silicon-slag refining was introduced and several types of imposing slag were reviewed. Boron removal from silicon using Si-based alloy and novel slag with active component were mentioned, and effects of slag refining processing parameters were discussed. According to the investigations, slag refining technique can remove a large amount of boron from MG-Si, and the potential industrial applications of slag refining technique were proposed.

Keywords: solar grade silicon, metallurgical grade silicon, slag refining, B removal.
\end{abstract}

\begin{abstract}
Представлен принцип переработки кремниевого шлака, рассмотрены несколько типов шлака. Было упомянуто об удалении бора из кремния с использованием сплава на основе кремния (Si) и нового шлака с активным компонентом, обсуждается әфреккт от процесса рафинирования шлака. Согласно исследованиям, процесс рафинирования шлака может удалить большое количество бора из MG-Si (металлургического кремния), а также предложена потенциальная промышленная технология рафинирования шлака.
\end{abstract}

Технологія переробки шлаку для металургійного процесу очищення кремнію: огляд. Rowaid Al-khazraji, Yaqiong Li, Lifeng Zhang

Представлено принцип переробки кремніевого шлаку, розглянуто кілька типів шлакових систем. Розглядається видалення бору з кремнію з використанням сплаву на основі кремнію (Si) та нового шлаку з активним компонентом, обговорюваються наслідки від параметрів рафінування шлаку. За даними досліджень, технологія рафінування шлаку дозволяе видалити велику кількість бору з MG-Si (металургійного кремнію), запропоновано потенційне застосування у промисловості технологій рафінування шлаку.

\section{Introduction}

Application of solar energy comprises $0.24 \%$ of the global energy resource and $4.67 \%$ of renewable energy resource and wich raises up rapidly [1]. The solar cell has big attention currently and the need for solar grade silicon (SOG-Si, purity of 99.9999\%) feedstock has been growing rapidly. Boron impurity in Si solar cells plays a major role in reducing photoelectric conversion efficiency through accelerating auger recombination and reducing the lifetime of minority carriers, and moreover, the metastable defects $\left(\mathrm{BO}_{n}\right)$, deep energy levels boric, and ferrous compounds are the main factors for cell decay. Most common routes to produce SOG-Si from metallurgical grade silicon 
(MG-Si, purity of 98 99\%) is still based on Siemens technology, which is considered an energy-intensive method and generates significant amounts of chemical wastes. In recent years, more economic effective metallurgical processes for SOG-Si production have been studied and developed, such as directional solidification $[2,3]$, acid leaching $[4,5]$, solvent refining $[6,7]$, plasma refining, vacuum process [8, 9], and slag refining $[10,11]$.

For solar cell application, the impurity level for elements should not exceed 1 ppmw [12]. Most impurities in MG-Si, especially metal elements, can be eliminated to the required content by directional solidification. However, this method is useless for the impurity with large segregation coefficient, such as B [13]. Moreover vacuum refining treatment shows no effect on $\mathrm{B}$ because of its low vapor pressure $\left(10^{-6} \mathrm{~Pa}\right.$ at $1773 \mathrm{~K}$ ) [14]. It is noting that the molten slag like $\mathrm{CaO}-\mathrm{SiO}_{2}$ based systems (i.e. $\mathrm{CaO}-\mathrm{SiO}_{2}$, $\mathrm{CaO}-\mathrm{SiO}_{2}-\mathrm{CaF}_{2}, \mathrm{CaO}-\mathrm{SiO}_{2}-\mathrm{Al}_{2} \mathrm{O}_{3}, \mathrm{CaO}-\mathrm{SiO}_{2}-$ $\mathrm{Na}_{2} \mathrm{O}$, and so on) are efficient agents for $\mathrm{B}$ removal, which are common used in steel making industry. This current paper extensively reviews relevant theoretical and experimental studies in this field.

\section{Basic principle}

\subsection{Principle of slag refining}

Slag refining is one of the metallurgical methods used to remove B impurity from MGSi. It includes melting MG-Si in the presence of a slag to remove B impurity. Slag refining has lower equipment cost with less energy consumption. It can be brief in reacting slag with MG-Si to oxidize impurities at Si/slag interface in the first step, and draw it from the interface to slag phase in the second step. The $\mathrm{B}$ impurity can be oxidized to $\mathrm{BO}, \mathrm{B}_{2} \mathrm{O}_{3}, \mathrm{~B}_{2} \mathrm{O}, \mathrm{BO}_{2}$, and $\mathrm{B}_{2} \mathrm{O}_{2}$ gas by slag treatment and evaporated at 1685-2500 K [14]. From Ellingham oxides diagram [15], B has higher Gibbs free energy $(\Delta \mathrm{G})$ than Si which means B removal is a little hard. The major attempts in the purification of MGSi using slag have been focused on determining equilibrium conditions between $\mathrm{Si}$ and slag and optimizing slag chemistry, including its basicity $\left(\mathrm{CaO} / \mathrm{SiO}_{2}\right)$ and oxygen potential $\left(\mathrm{P}_{\mathrm{O} 2}\right)$, so that the removal efficiency of these elements maximized. The $\mathrm{B}$ oxidation reaction at the $\mathrm{Si} /$ slag interface can be expressed by the following chemical reaction:

$$
\mathrm{B}+\frac{3}{4} \mathrm{O}_{2}=\frac{1}{2} \mathrm{~B}_{2} \mathrm{O}_{3}
$$

The slag absorbs $\mathrm{B}$ oxide $\left(\mathrm{B}_{2} \mathrm{O}_{3}\right)$ in form of borate $\left(\mathrm{BO}_{3}^{3-}\right)$ as following reaction:

$$
\frac{1}{2} \mathrm{~B}_{2} \mathrm{O}_{3}+\frac{3}{2} \mathrm{O}^{2-}=\mathrm{BO}_{3}^{3-}
$$

Oxide ion $\left(\mathrm{O}^{2-}\right)$ in the above reaction is provided by the slag through dissociation of basic oxides such as $\mathrm{CaO}, \mathrm{BaO}$, or $\mathrm{Na}_{2} \mathrm{O}$ as expressed in reaction (3), while under equilibrium conditions the oxygen potential is established through reaction (4) as the dominant metal/oxide phases.

$$
\begin{gathered}
\mathrm{CaO}=\mathrm{Ca}^{2+}+\mathrm{O}^{2-} \\
\mathrm{SiO}_{2}=\mathrm{Si}+\mathrm{O}_{2}
\end{gathered}
$$

The distribution coefficient of $\mathrm{B}\left(L_{\mathrm{B}}\right)$ used to evaluate the $\mathrm{B}$ removal from $\mathrm{Si}$ is expressed by equation (5):

$$
L_{\mathrm{B}}=\frac{(\% B) \text { in slag }}{[\% B] \text { in } \mathrm{Si}}
$$

\subsection{Thermodynamic analysis of slag treatment}

Oxidation reaction of $\mathrm{B}$ at the interface between Si and slag can be given by equation (1). For slag containing silica, oxygen is generated as shown in equation (4). Combining equation (1) and (4) gives the total equation (6):

$$
\frac{3}{4}\left(\mathrm{SiO}_{2}\right)+[\mathrm{B}]=\left(\mathrm{BO}_{1.5}\right)+\frac{3}{4} \mathrm{Si}
$$

Therefore, the equilibrium constant for this reaction is obtained by equations (7):

$$
\mathbf{K}=\frac{\alpha_{B O_{1.5}} \alpha_{S i}^{3 / 4}}{\alpha_{S i O_{2}}^{3 / 4} \alpha_{B}}
$$

Where $\alpha$ is the activity of the component $i$, and it is expressed by the mole fraction and the activity coefficient of component $i\left(\gamma_{i}\right)$ as shown in the following equation:

$$
\alpha_{1}=\gamma_{1} x_{1}
$$

Equation (7) can be re-written as the following equations:

$$
\begin{gathered}
\mathrm{K}=\frac{\alpha_{\mathrm{BO}_{1.5}}\left(\alpha_{\mathrm{Si}}\right)^{3 / 4}}{\alpha_{\mathrm{B}}\left(\alpha_{\mathrm{SiO}_{2}}\right)^{3 / 4}}=\frac{\gamma_{\mathrm{BO}_{1.5}} X_{\mathrm{BO}_{1.5}}}{\gamma_{\mathrm{B}} X_{\mathrm{B}}} \cdot\left(\frac{\alpha_{\mathrm{Si}}}{\alpha_{\mathrm{SiO}_{2}}}\right)^{3 / 4} \\
L_{\mathrm{B}}=\frac{X_{\mathrm{BO}_{1.5}}}{X_{\mathrm{B}}}=\frac{\mathrm{K} \gamma_{\mathrm{B}}}{\gamma_{\mathrm{BO}_{1.5}}} \cdot\left(\frac{\alpha_{\mathrm{SiO}_{2}}}{\alpha_{\mathrm{Si}}}\right)^{3 / 4}
\end{gathered}
$$

where $X_{\mathrm{BO} 1.5}$ and $X_{\mathrm{B}}$ are the B contents in slag and $\mathrm{Si}$ after slag treatment, respectively; $\alpha_{i}$ and $\gamma_{i}$ are the activity and activity coefficient of the component $i$, respectively; $\mathrm{K}$ is the equilibrium constant of the reaction; and $L_{\mathrm{B}}$ is the partition coefficient of B. From equation (10), it can be seen that $L_{\mathrm{B}}$ is affected by the activ- 
ity coefficient of $\mathrm{B}$ in the Si phase, the activity coefficient of $\mathrm{BO}_{1.5}$ in the slag phase, the oxygen partial pressure, temperature, and the slag composition.

\section{Different slags used for MG-Si refining}

Several slag systems have been proposed for MG-Si treatment, including $\mathrm{CaO}-\mathrm{SiO}_{2}$ [16-18], $\mathrm{Na}_{2} \mathrm{O}-\mathrm{SiO}_{2}[19,20], \mathrm{CaO}-\mathrm{SiO}_{2}-\mathrm{CaF}_{2}[16,21$, 22], $\mathrm{BaO}-\mathrm{SiO}_{2}-\mathrm{Al}_{2} \mathrm{O}_{3}$ [10], $\mathrm{CaO}-\mathrm{SiO}_{2}-\mathrm{Al}_{2} \mathrm{O}_{3}-$ $\mathrm{MgO}$ [10], and so on. Different experiments and researches of slag refining using different experimental conditions have been reviewed and discussed below.

\subsection{MG-Si purification by slag refining using binary slag system}

Generally, $\mathrm{CaO}-\mathrm{SiO}_{2}$ slag system is used for the removal of $\mathrm{B}$ individually or combined with other additives, which made the $\mathrm{CaO}-\mathrm{SiO}_{2}$ system more important and basic. The changes in the composition of this binary system could affect the B removal efficiency. The amount of $B$ removal by slag treatment is a function of $\mathrm{CaO} / \mathrm{SiO}_{2}$ ratio (basicity), oxygen contents in slag, and free oxygen ions. Teixeira et al. [16], Wu et al. [17], and Wei et al. [18] studied the B removal from MG-Si using $\mathrm{CaO}-\mathrm{SiO}_{2}$ slag. Wu et al. [17] worked to refine MG-Si using $\mathrm{SiO}_{2}$. The result shows that the process needs quite high temperature and the final $\mathrm{B}$ content in $\mathrm{Si}$ is above the SOG-Si level. The B removal efficiency is greatly improved with the addition of basic oxide $\mathrm{CaO}$ to $\mathrm{SiO}_{2}$, because the high oxygen contents are necessary to oxidize $\mathrm{B}$ as $\mathrm{B}_{2} \mathrm{O}_{3}$, and the high basicity provides free oxygen ions to absorb $\mathrm{B}_{2} \mathrm{O}_{3}$ into the slag phase. Additionally, the $\mathrm{CaO}-\mathrm{SiO}_{2}$ phase diagram shows that increasing the $\mathrm{SiO}_{2}$ content appropriately is beneficial to decrease the melting point of the slag. When the content of $\mathrm{SiO}_{2}$ is $42.3 \% \sim 61.3 \%$, the melting point of slag is ranging from $1710 \mathrm{~K}$ to $1813 \mathrm{~K}$, which is higher than that of Si. Therefore, the slag treatment needs high heating temperature above $1710 \mathrm{~K}$.

Compared to the commonly used $\mathrm{CaO}-\mathrm{SiO}_{2}$ slag system, the $\mathrm{Na}_{2} \mathrm{O}-\mathrm{SiO}_{2}$ slag [19] shows relatively low melting point, density, surface tension, and viscosity. The removal rate of $\mathrm{B}$ increases with increasing $\mathrm{Na}_{2} \mathrm{O}$ concentration in slag, and the $\mathrm{B}$ is removed at the slag/gas interface in the form of $\mathrm{Na}_{2} \mathrm{~B}_{2} \mathrm{O}_{4}$, which is a volatile compound. Finally, $91 \%$ of B was removed by using $50 \% \mathrm{NaO}-\mathrm{SiO}_{2}$ slag at $1823 \mathrm{~K}$. Fang et al. [20] investigated the $\mathrm{B}$ removal by multiple slag operations with $\mathrm{Na}_{2} \mathrm{O}-\mathrm{SiO}_{2}$ slag. The B content decreased from 10.6 to 10.6 ppmw by one slag treatment and the removal efficiency of B with slag refining in once, twice and three times was $93.87 \%, 96.96 \%$, and $98.68 \%$, respectively.

\subsection{MG-Si purification by slag refining using ternary slag system}

In order to promote $\mathrm{B}$ removal, enhancing slag chemistry is considered an important factor, such as slag basicity, viscosity, and melting point. This leads to the modification of the binary slag system to ternary slag system by adding active agents. $\mathrm{Wu}$ et al. [23] and $\mathrm{Li}$ et al. [24] studied the effect of $\mathrm{K}_{2} \mathrm{CO}_{3}$ addition to $\mathrm{CaO}-\mathrm{SiO}_{2}$ slag during the purification process. Their results show that the addition of high basic $\mathrm{K}_{2} \mathrm{CO}_{3}$ can improve the mass transfer of $\mathrm{B}$ in slag, and therefore increased the removal efficiency of B. Teixeira et al. [16], Luo et al. [21], and Jing et al. [22] added $\mathrm{CaF}_{2}$ to $\mathrm{CaO}-$ $\mathrm{SiO}_{2}$. The $\mathrm{CaF}_{2}$ addition provided a broader of basicity range compared to the binary systems, but it did not obviously improve the LB. $\mathrm{CaF}_{2}$ is neither as acidic as silica nor as basic as $\mathrm{CaO}$ and hence it dilutes both compounds in the slag phase. The addition of $\mathrm{CaF}_{2}$ leads to de-polymerization of silicate network by $\mathrm{F}$ which has the ability to move between silicate anions and free the $\mathrm{O}_{2}$ from the $\mathrm{SiO}_{2}$, thereby decreasing the electrostatic bound and lowering the viscosity of the slag. The obtained $\mathrm{O}_{2}$ facilitates the removal of B in the Si/slag interface. Furthermore, the reaction between $\mathrm{CaF}_{2}$ and $\mathrm{SiO}_{2}$ can form $\mathrm{CaO}$, resulting in a higher basicity. So the addition of $\mathrm{CaF}_{2}$ can expand the range of basicity and facilitate the removal of B. In case of using lithium compounds with slag, Wu et al. [25], Ding et al. [26], and Lai et al. [27] investigated the $\mathrm{SiO}_{2}-\mathrm{CaO}-\mathrm{Li}_{2} \mathrm{O}$ and $\mathrm{SiO}_{2}-\mathrm{CaO}-\mathrm{LiF}$ ternary slag systems. $\mathrm{LiF}$ can lower the slag's viscosity, and $\mathrm{Li}_{2} \mathrm{O}$ can react with many metal oxides, (i.e. $\mathrm{CuO}, \mathrm{Fe}_{2} \mathrm{O}_{3}$ ) and non-metal oxides, (i.e. $\mathrm{B}_{2} \mathrm{O}_{3}$ and $\mathrm{P}_{2} \mathrm{O}_{5}$ ). It is worth noting that the addition of $\mathrm{Li}_{2} \mathrm{O}$ or $\mathrm{LiF}$ to $\mathrm{SiO}_{2}-\mathrm{CaO}$ constitute more effective ways for the $\mathrm{B}$ removal. With increasing $\mathrm{Li}_{2} \mathrm{O}$ content, the basicity of slag increases, which reinforces the slag ability to absorb $\mathrm{B}$ oxides and increase $\mathrm{L}_{\mathrm{B}}$ value. Nishimoto et al. [28] proposed to optimize $\mathrm{B}$ removal by combining $\mathrm{CaO}-\mathrm{SiO}_{2}$ slag treatment with $\mathrm{Cl}_{2}$ gaseous at $1823 \mathrm{~K}$, resulting in the reduction and removal of $\mathrm{B}$ content as B-O-Cl form. Wang et al. [29] and Lu et al. [30] added $\mathrm{CaCl}_{2}$ to $\mathrm{CaO}-\mathrm{SiO}_{2}$ slag, which reduced the melting point and viscosity of slag. B can react with the slag at the slag/Si interface, and then enter into the slag as $\mathrm{BO}_{1.5}$. And $\mathrm{BO}_{15}$ can react with $\mathrm{CaCl}_{2}$ in the molten slag to form $\mathrm{B}-\mathrm{O}-\mathrm{Cl}$ with a high vapor pressure resulting in the evaporation of B from the slag. Lu et al. [31] used $\mathrm{CaO}-\mathrm{SiO}_{2}$ slag system with intermit- 


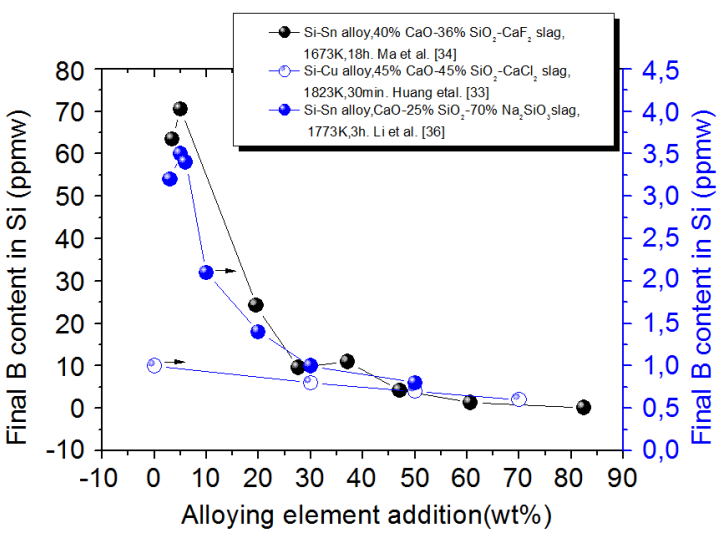

Fig. 1. Effect of alloying element on the final B content in $\mathrm{Si}$

tent $\mathrm{CaCl}_{2}$ addition. The results showed that the intermittent $\mathrm{CaCl}_{2}$ addition promotes the elimination of $\mathrm{B}$. Wu et al. [32] studied the combined method consisting slag treatment and gas blowing. The B concentration decreased from 22 ppmw to 0.75 ppmw by using $42.5 \% \mathrm{CaO}-$ $\mathrm{SiO}_{2}-15 \% \mathrm{CaCl}_{2}$ slag and $40 \% \mathrm{Ar}-20 \% \mathrm{O}_{2}-\mathrm{H}_{2} \mathrm{O}$ gas composition. They found it is helpful to remove B by adding water vapor into the oxygen, because the partial pressure of the gaseous boric hydrate species is much higher than that of gaseous boric oxide species. Luo et al. [21] used $\mathrm{CaO}-\mathrm{SiO}_{2}-\left(\mathrm{Na}_{2} \mathrm{O}, \mathrm{Al}_{2} \mathrm{O}_{3}\right)$ slag for the slag refining. The $\mathrm{CaO}-\mathrm{SiO}_{2}-\left(\mathrm{Na}_{2} \mathrm{O}, \mathrm{Al}_{2} \mathrm{O}_{3}\right)$ ternary slag showed better results compared to the $\mathrm{CaO}-$ $\mathrm{SiO}_{2}$ binary slag under the same experimental conditions. The $\mathrm{L}_{\mathrm{B}}$ was 2.1 after $\mathrm{CaO}-\mathrm{SiO}_{2}$ slag treatment, while the $\mathrm{L}_{\mathrm{B}}$ in the $\mathrm{CaO}-\mathrm{SiO}_{2}-\mathrm{Na}_{2} \mathrm{O}$ and $\mathrm{CaO}-\mathrm{SiO}_{2}-\mathrm{Al}_{2} \mathrm{O}_{3}$ can respectively increase to 4 and 6.5 .

\subsection{MG-Si purification by slag refining using quaternary slag system}

More attempts were used to enhance the slag refining efficiency by using quaternary slag. Johnston et al. [10] investigated $\mathrm{Al}_{2} \mathrm{O}_{3}-\mathrm{CaO}-$ $\mathrm{MgO}-\mathrm{SiO}_{2}$ slag. They found that $L_{\mathrm{B}}$ reached the maximum value of about 1.5 when the basicity was 0.8 . It shown that the slag with strongly basic and oxidizing features would be useful for B removal from Si. Yuan et al. [33] studied slag refining using $\mathrm{SiO}_{2}-\mathrm{CaO}-\mathrm{Na}_{3} \mathrm{AlF}_{6}-\mathrm{Ca}-$ $\mathrm{SiO}_{3}$ slag, and the $\mathrm{B}$ content decreased from 14 ppmw to 0.436 ppmw by using $23.12 \% \mathrm{SiO}_{2}-$ $\mathrm{CaO}-16.83 \% \mathrm{Na}_{3} \mathrm{AlF}_{6}-49.61 \% \mathrm{CaSiO}_{3}$ slag. The $\mathrm{B}$ contents in Si are strongly affected by slag composition and addition of $\mathrm{Na}_{3} \mathrm{AlF}_{6}-\mathrm{CaO}$ to $\mathrm{CaSiO}_{3}$ slag. Table 1 summarizes the slag refining with different slag systems results.

\subsection{Si-based alloy refining using slag system}

With the development of slag treatment, the $\mathrm{B}$ content in MG-Si decreased gradually, which resulted in the lack of mass transfer, reaction process, and the low activity of B. Although the increase of melting temperature can increase the activity of $\mathrm{B}$ in $\mathrm{Si}$ phase, but the refining cost increased. In order to improve the $L_{B}$ and B removal efficiency, MG-Si can be alloy with another element as the first step and treated it with slag in the following step. Huang et al. [34] reported the purification of $\mathrm{Si}-\mathrm{Cu}$ alloy by using $\mathrm{CaO}-\mathrm{SiO}_{2}-\mathrm{CaCl}_{2}$ slag. The $\mathrm{B}$ contents reduced from 3.12 ppmw to 0.35 ppmw, and B contents decreased from 3.12 to $1.01 \mathrm{ppmw}$ without the addition of $\mathrm{Cu}$ in the experiment under the same conditions. Ma et al. [35, 36] investigated a sequential refining process of MG-Si composed of Si-Sn solvent refining, slag treatment, and acid leaching. In their work, the prepared Si-Sn alloy was treated with $\mathrm{CaO}-\mathrm{SiO}_{2}-\mathrm{CaF}_{2}$ slag with different slag to alloy mass ratio. $\mathrm{B}$ content was found to be decreased from 33 ppmw to 0.3 ppmw, and there was an increasing in LB with increasing $\mathrm{Sn}$ contents in $\mathrm{Si}-\mathrm{Sn}$ alloy due to the increasing $\mathrm{B}$ activity coefficient and oxygen partial pressure. Li et al. [37] combined Si-Cu solvent refining and $\mathrm{CaO}-\mathrm{SiO}_{2}-\mathrm{Na}_{2} \mathrm{O}-\mathrm{Al}_{2} \mathrm{O}_{3}$ slag treatment. When the $\mathrm{Si}$ alloyed with $\mathrm{Cu}$ or Sn, the B removal efficiency after slag refining can be improved remarkably. Fig. 1 shows the relationship between alloying element and final B content in $\mathrm{Si}$. As shown in this figure, the $\mathrm{B}$ removal is favorable with higher metal compositions. According to equation (10), alloying metal such (as $\mathrm{Cu}$ and $\mathrm{Sn}$ ) has the ability to decrease the activity of silicon or/and increase the activity coefficient of $\mathrm{BO}_{1.5}$. This resulted in an increase in the $\mathrm{L}_{\mathrm{B}}$. Although the $\mathrm{Cu}$ content in the refined $\mathrm{Si}$ increased, it can be removed in the following refining step. For example, directional solidification is an unavoidable refining step for SOG-Si production through any integrated metallurgical route, $\mathrm{Cu}$ and $\mathrm{Sn}$ can be removed in this step.

\section{Influencing factors on slag refining process}

MG-Si treated by slag refining with various temperatures, holding time, and heating methods could exhibit different refining results. For instance, increasing the temperature leads to reduce in $\mathrm{B}$ contents as shown in Fig. 2(a), because the high temperature can reduce slag viscosity and increase the silica activity in the slag. Additionally, holding time is an important parameter affecting B removal, as shown in Fig. 2(b). In the first $30 \mathrm{~min}$, the B content was significantly reduced, but as time continued to increase, the B content did not change significantly and only slightly decreased. This is because as the content of $\mathrm{B}$ in $\mathrm{Si}$ decreases, 


\begin{tabular}{|c|c|c|c|c|c|c|c|c|c|c|c|c|c|c|c|c|c|c|c|c|c|}
\hline 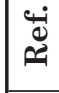 & $\stackrel{\square}{\Xi}$ & $\stackrel{\infty}{\Xi}$ & $\begin{array}{l}\overline{\mathfrak{N}} \\
\stackrel{\mathcal{U}}{ }\end{array}$ & 壳 & $\stackrel{\sigma}{\Xi}$ & $\underset{\stackrel{\sim}{\sim}}{\bar{s}}$ & 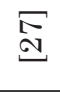 & 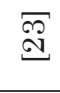 & $\underset{\mathcal{I}}{\mathbb{I}}$ & $\overline{\vec{\Xi}}$ & $\stackrel{\mathbb{N}}{\mathbb{N}}$ & 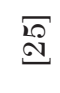 & 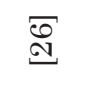 & $\underset{\mathrm{N}}{\mathbb{N}}$ & 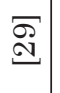 & $\vec{\sigma}$ & $\begin{array}{l}\infty \\
\stackrel{\infty}{N}\end{array}$ & $\underset{\mathscr{N}}{\mathbb{్}}$ & 옴 & 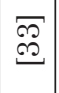 & 原 \\
\hline 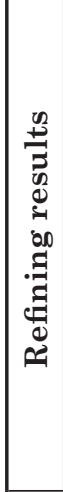 & 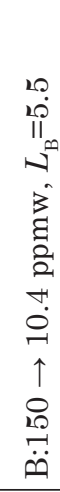 & 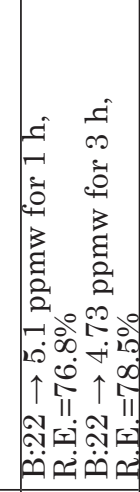 & 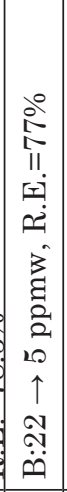 & 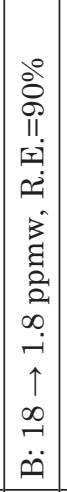 & 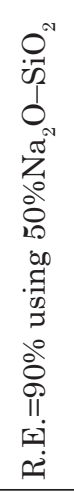 & 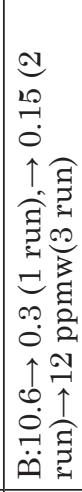 & 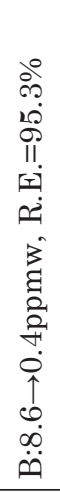 & 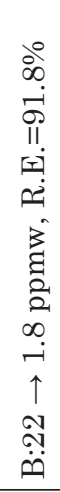 & 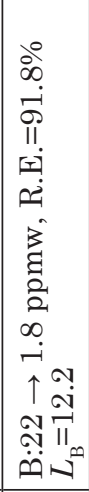 & 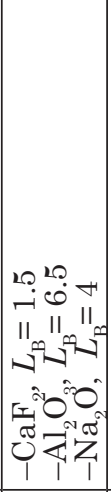 & 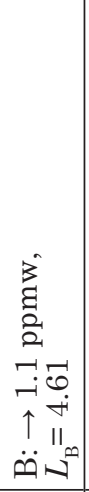 & 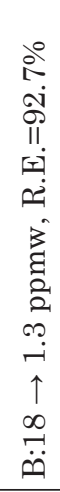 & 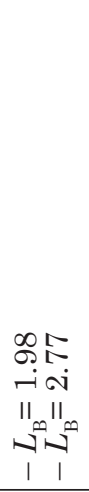 & 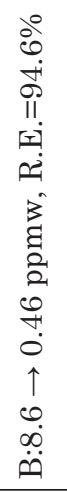 & 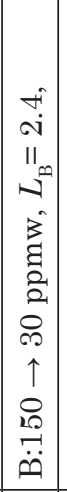 & 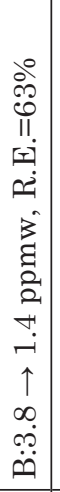 & 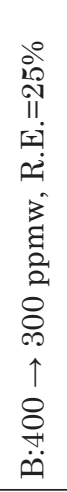 & 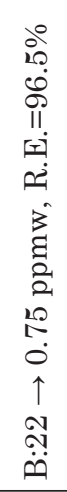 & $\begin{array}{l}0 \\
\stackrel{T}{~} \\
\pi_{\infty} \\
\sim\end{array}$ & 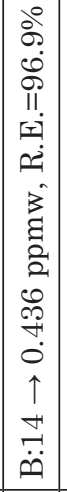 & 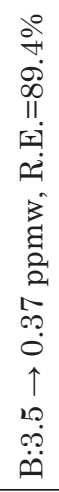 \\
\hline & & & & & & $\frac{1}{10}$ & & $\dot{0}$ & & & & & & & $e_{\pi}^{1}$ & & & & & & \\
\hline
\end{tabular}

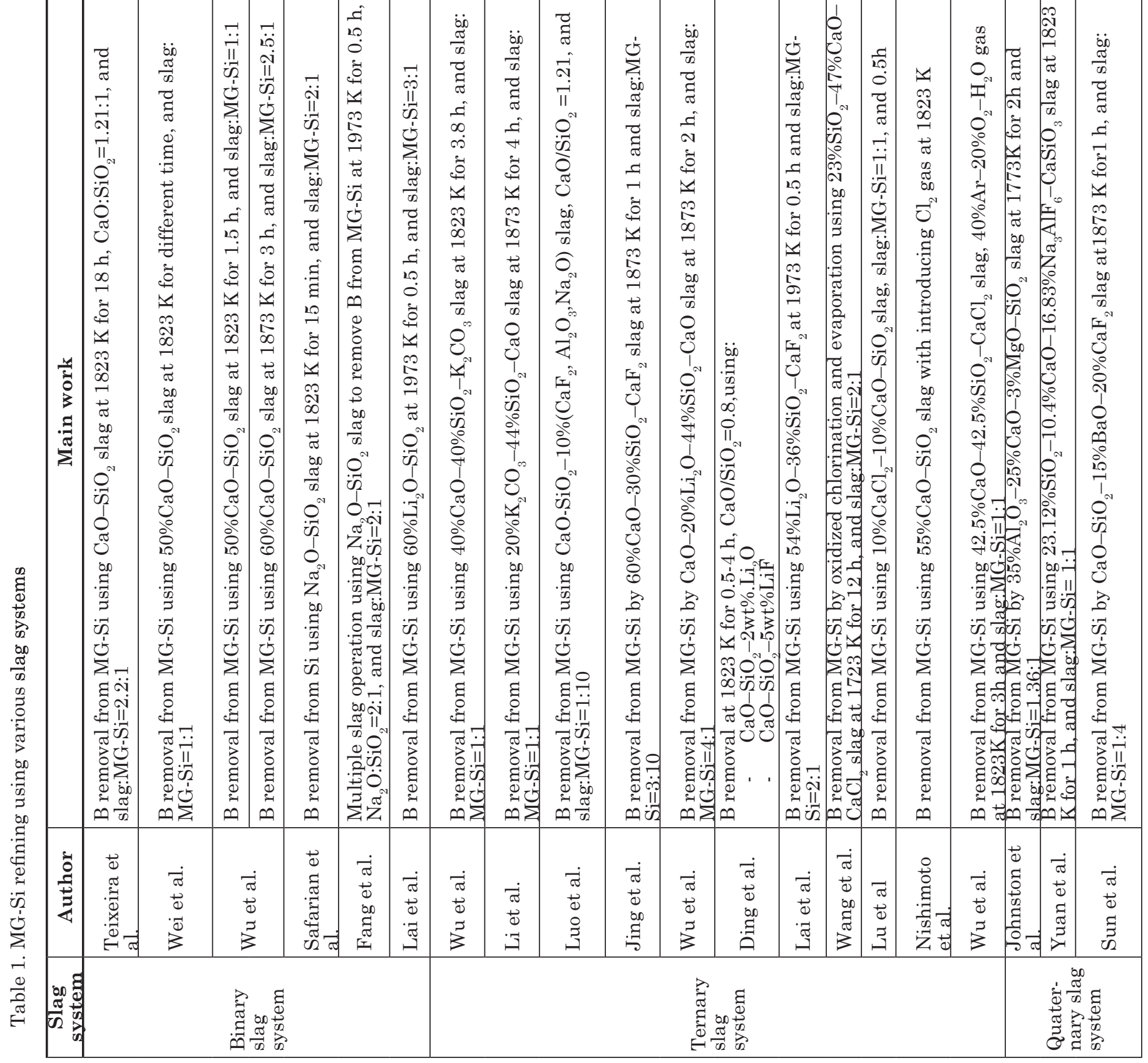


the kinetic behavior of the $\mathrm{B}$ hindered, which results in longer time for $\mathrm{B}$ removal by the slag treatment. It could be concluded that B oxidation reached equilibrium after $30 \mathrm{~min}$.

Slag refining can also be affected by the heating manner. Wu et al. [38] in their work investigated the effect of heating method on $\mathrm{B}$ removal. The results shown that when the slag refining is performed using an resistance furnace, the boron removal efficiency reaches $42.1 \%$, while when slag refining is performed using an electromagnetic induction furnace, the boron removal efficiency reaches $83.15 \%$. Obviously, the heating manner of electromagnetic induction accelerates the refining reaction, which causes a sharp increase of efficiency of $\mathrm{B}$ removal.

\section{Conclusion}

Slag refining is the main refining method for removing boron impurities in silicon. It uses slag to oxidize B impurity to reduce its content in Si. According to literature review, the conclusions were summarized as follows.

Changing the slag basicity shows a big influence on $\mathrm{B}$ removal from $\mathrm{Si}$, where $\mathrm{SiO}_{2}$ provides oxygen potential to oxidize $\mathrm{B}$ and $\mathrm{CaO}$ provides the oxygen ions to absorb $\mathrm{B}$ oxide into the slag. Therefore a suitable balance ratio between these two oxides is needed to enhance B removal.

Additive agents are quite helpful for the slag process, because it added to $\mathrm{CaO}-\mathrm{SiO}_{2}$ slag can decrease melting point, viscosity and adjust slag basicity, which aims to enhance B removal. It is worth mentioning that $\mathrm{CaF}_{2}$ can reduce the liquidus temperature of the slag and enhance the mass transfer process, and $\mathrm{CaCl}_{2}$ can be used to promote B removal as gas product.

Slag refining of Si alloy has shown very large $L_{\mathrm{B}}$ and the $\mathrm{B}$ removal efficiency because of the increasing the activity coefficient of $\mathrm{B}$ and the decreasing activity of $\mathrm{SiO}_{2}$. It provided a favorable condition for removal of alloy phase by selective acid leaching.

The slag refining application for $\mathrm{Si}$-alloy has a high potential for better B removal from MGSi. Although it can not avoid the introduction of alloying metal as impurities into the refined $\mathrm{Si}$, it can be removed through directional solidification refining step. Therefore, this process is considered as a low-cost treatment comparing to Siemens process.

\section{Acknowledgments}

The authors are grateful for support from the National Science Foundation China (Grant No. 51334002, No. 51604023), Beijing
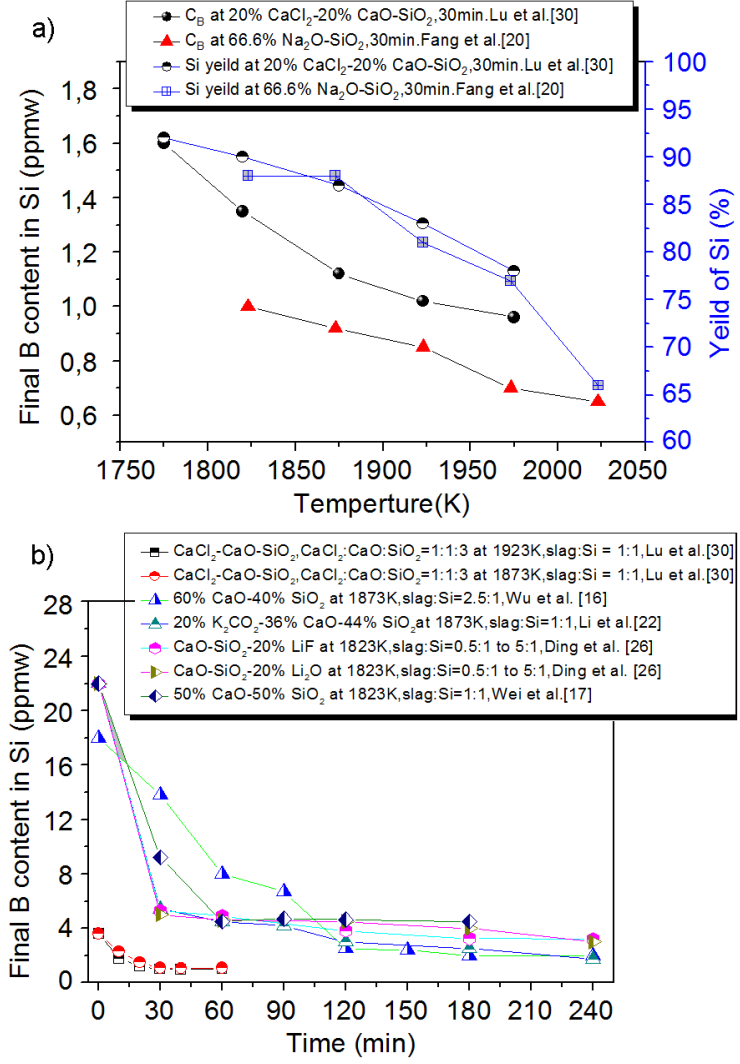

Fig. 2. (a) Effect of temperature on the final B content and Si yield, and (b) effect of holding time on final B content after slag refining.

Science \& Technology Program (Grant No. Z171100002217063) and Postdoctoral Foundation China (Grant No. 2015M580985), Beijing Key Laboratory of Green Recycling and Extraction of Metals (GREM), the Laboratory of Green Process Metallurgy and Modeling (GPM2) at the School of Metallurgical and Ecological Engineering at University of Science and Technology Beijing (USTB), China.

\section{References}

1. C.Xu, C.Pan, Y.Liu, Z. L.Wang, Nano Energy, 1, 259 (2012).

2. M. Martorano, J. F. Neto, T. Oliveira, T. Tsubaki, Mater. Scie. Eng.: B, 176, 217 (2011).

3. S. Sun, Y. Tan, W. Dong, H. Zhang, J. Zhang, J. Mater. Eng. Perform., 21, 854 (2012).

4. I. Santos et al., Hydrometall., 23, 237 (1990).

5. V. Lashgari, H. Yoozbashizadeh, ASM Scie.J., 1, 37 (2007).

6. Z. Yin, A. Oliazadeh, S. Esfahani, M. Johnston, M. Barati, Canadian Metall. Quart., 50, 166 (2011).

7. S. Esfahani, M. Barati, Met. Mater. Int., 17, 1009 (2011).

8. K. Hanazawa, N. Yuge, Y. Kato, Mater. Trans., 45, 844 (2004). 
9. K. Hanazawa, N. Yuge, S. Hiwasa, Y. Kato, J.Japan Inst.Metal., 67, 569 (2003).

10. M. Johnston, M. Barati, Sol. Energy Mater.Sol. Cells, 94, 2085 (2010).

11. M. D. Johnston, L. T. Khajavi, M. Li, S. Sokhanvaran, M. Barati, JOM, 64, 935 (2012).

12. A. M. Mitrašinović, T. A. Utigard, Silicon, 1, 239 (2009).

13. B.R.Bathey, M.C.Cretella, J. Mater. Sci., 17, 3077 (1982).

14. J.J.Wu, Y.Bin, Y.DAI, K.Morita, Trans.Nonferr Met. Soc. China, 19, 463 (2009).

15. E. T. Turkdogan, (1980).

16. L. A. V.Teixeira, K.Morita, ISIJ Int., 49, 783 (2009).

17. J.Wu, Y.Li, K.Wei, Y.Bin, Y.Dai, Trans.Nonferr Met. Soc. China, 24, 1231 (2014).

18. K.X.Wei et al., Rare Metals, 34, 522 (2015).

19. J.Safarian, G.Tranell, M.Tangstad, Metall. Mater. Trans. B, 44, 571 (2013).

20. M.Fang et al., Ind.Eng. Chem. Res., 53, 12054 (2014).

21. D.Luo, L.Ning, Y.Lu, G.Zhang, T.Li, Transactions of Nonferrous Metals Society of China, 21, 1178 (2011).

22. C.Jing, J.Li, W.Chen, C.Chao, X.Luo, Trans. Nonferr Met. Soc. China, 21, 1402 (2011).

23. J.Wu, F.Wang, W.Ma, Y.Lei, B.Yang, Metall. Mater. Trans. B, 47, 1796 (2016).

24. Y.Li, J.Wu, W.Ma, B.Yang, Silicon, 7, 247 (2015).
25. J. Wu et al., J.Non-Crystal. Sol., 358, 3079 (2012).

26. Z.Ding et al., J.Non-Crystall.e Solids, 358, 2708 (2012).

27. H.Lai et al., JOM, 1 (2015).

28. H. Nishimoto, K. Morita, Supplemental Proceedings: Materials Processing and Energy Materials, 1, 701 (2011).

29. Y.Wang, X.Ma, K.Morita, Metall.Mater. Trans. $B$, 45, 334 (2014)

30. C. Lu et al., Sep. Scie..Technol., 50, 2759 (2015).

31. C. Lu, T. Tang, Z. Sheng, P. Xing, X. Luo, Vacuum, 143, 7 (2017).

32. J. Wu, Y. Zhou, W. Ma, M. Xu, B. Yang, Metall. Mater. Trans. B, 48, 22 (2017).

33. S.L.Yuan, H.M.Lu, P.P.Wang, C.G.Tian, Z.J.Gao, Rare Metals, 1 (2014)

34. L.Huang et al., Separ. Purif. Techn., 170, 408 (2016).

35. X.Ma, T.Yoshikawa, K.Morita, Sep. Scie..Technol., 125, 264 (2014).

36. X.Ma, T.Yoshikawa, K.Morita, Metall.Mater. Trans. B, 44, 528 (2013).

37. M.Li, T.Utigard, M.Barati, Metall.Mater. Trans. $B$, 45, 221 (2014).

38. J. Wu et al., Mater. Scie. Semicond. Proc., 57, 59 (2017).

39. J.-L. Sun et al., Trans.Nonferr. Met. Soc. China, 26, 3299 (2016) 